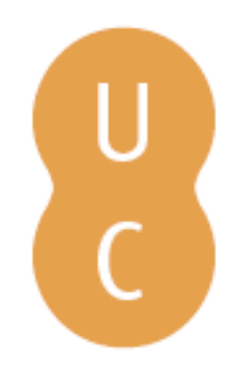

\title{
nombalina
}

\section{Prudência, descrição e sociabilidade cortesã em D. Francisco Manuel de Melo}

\author{
Autor(es): $\quad$ Pereira, Paulo Silva
}

Publicado por: Imprensa da Universidade de Coimbra; Ediciones Universidad

URL

persistente: URI:http://hdl.handle.net/10316.2/31503

DOI: $\quad$ DOI:http://dx.doi.org/10.14195/978-989-26-0245-5_2

Accessed : $\quad$ 26-Apr-2023 12:53:23

A navegação consulta e descarregamento dos títulos inseridos nas Bibliotecas Digitais UC Digitalis, UC Pombalina e UC Impactum, pressupõem a aceitação plena e sem reservas dos Termos e Condições de Uso destas Bibliotecas Digitais, disponíveis em https://digitalis.uc.pt/pt-pt/termos.

Conforme exposto nos referidos Termos e Condições de Uso, o descarregamento de títulos de acesso restrito requer uma licença válida de autorização devendo o utilizador aceder ao(s) documento(s) a partir de um endereço de IP da instituição detentora da supramencionada licença.

Ao utilizador é apenas permitido o descarregamento para uso pessoal, pelo que o emprego do(s) título(s) descarregado(s) para outro fim, designadamente comercial, carece de autorização do respetivo autor ou editor da obra.

Na medida em que todas as obras da UC Digitalis se encontram protegidas pelo Código do Direito de Autor e Direitos Conexos e demais legislação aplicável, toda a cópia, parcial ou total, deste documento, nos casos em que é legalmente admitida, deverá conter ou fazer-se acompanhar por este aviso.

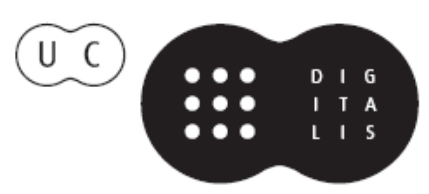


Marta Teixeira Anacleto

Sara Augusto

Zulmira Santos

Coordenação

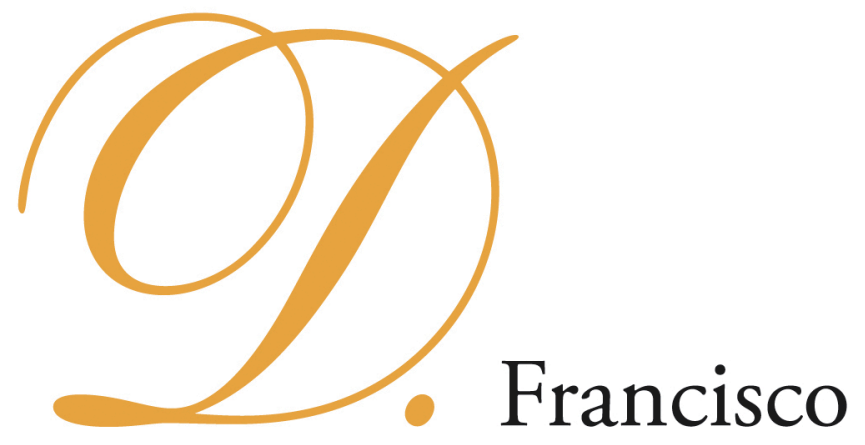

Manuel de Melo e o

Barroco Peninsular 


\title{
EDIĈ̣̃O
}

Imprensa da Universidade de Coimbra Ediciones Universidad Salamanca

\section{COORDENAÇÃo EDITORIAL}

Imprensa da Universidade de Coimbra

URL: http://www.uc.pt/imprensa_uc

Vendas online: http://www.livrariadaimprensa.com

\section{CONCEPÇÃO GRÁFICA}

António Barros

\section{REVISÃO TEXTO}

Sara Augusto

\author{
Pré-Impressão, Impressão e ACABamento \\ www.artipol.net
}

\section{IS B N}

978-989-26-0044-4 (Portugal)

978-84-7800-194-1 (Espanha)

DEPósito LEGAL

$311680 / 10$

OBRA PUBlicada COM O APOIO DE:

FCT Fundação para a Ciência e a Tecnologia

MINISTÉRIO DA CIÊNCIA, TECNOLOCIA E ENSINO SUPERIOR Portugal

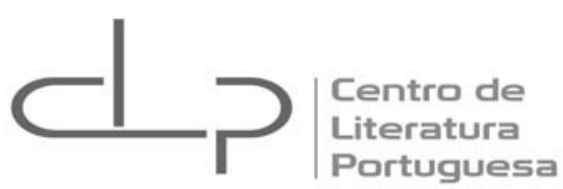

A presente publicação insere-se no Grupo "Poéticas" (coordenação de Marta Teixeira Anacleto) do Centro de Literatura Portuguesa, Unidade de I\&D financiada pela Fundação para a Ciência e a Tecnologia, ao abrigo do Programa Operacional Ciência e Inovação 2010.

(C) Agosto 2010

IMPRENSA DA UNIVERSIDADE DE COIMBRA

EDICIONES UNIVERSIDAD DE SALAMANCA 
Marta Teixeira Anacleto

Sara Augusto

Zulmira Santos

Coordenação

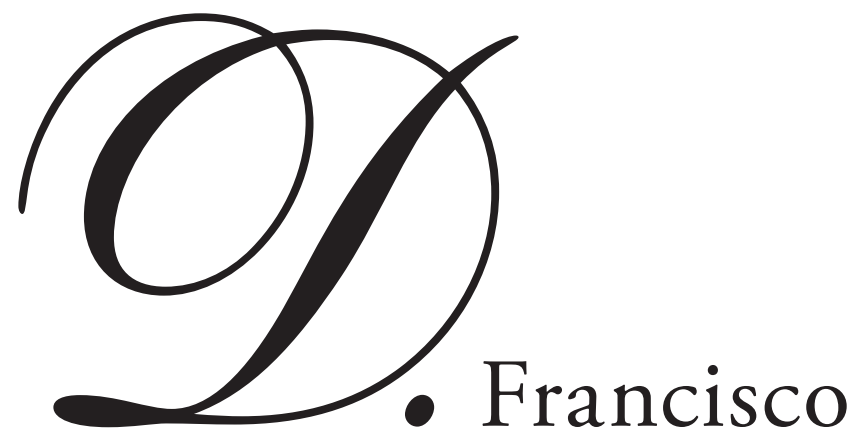

Manuel de Melo e o Barroco Peninsular

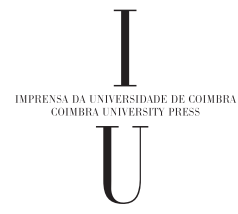


PARTE I

FORMAS E IMAGINÁRIO(s) DO BARROCO 


\author{
Paulo Silva Pereira \\ Centro de Literatura Portuguesa \\ Universidade de Coimbra
}

\title{
PRUDÊNCIA, DISCRIÇÃO E SOCIABILIDADE CORTESÁ EM D. FRANCISCO MANUEL DE MELO
}

Se há autor cujo trajecto existencial e cuja obra convidam o investigador a pôr de lado preconceitos de cunho nacionalista, esse autor é sem dúvida D. Francisco Manuel de Melo, pois ele encarna, como poucos, essa condição social e cultural de raiz peninsular que domina o tempo histórico aqui em apreço. Circunstâncias várias que podiam fazer deste caso um caso exemplar de encontro não foram se não - pelo menos, durante largo tempo - motivo de desencontro, originando artificiais processos de segmentaçáo da obra tendo por base critérios linguísticos e só verdadeiramente nas últimas décadas se tem levado a cabo uma pesquisa desassombrada e renovadora. Resistindo também à tentação de separar o que de si já traz uma substancial marca de organicidade, o estudo que agora se apresenta tem por base um universo de referência mais alargado e opera, de forma intencional, num registo de convergência entre o textual e o social.

Por entre os meandros da história literária e cultural, foi tomando forma uma certa imagem de autor e de homem que importa agora reconstruir, mas tendo sempre presente que, antes mesmo de ser convicção assumida pela comunidade de críticos e de investigadores, já muitos contemporâneos conseguiam reconhecer neste cortesão do século XVII os traços distintivos de uma identidade social e cultural, compósita e exigente, que tinha por pedra de toque tanto a prudência, como a discriçáo. Para isso, concorreu por certo um trabalho lento, mas intenso, de promoção - ou de encenação, num certo sentido - da sua própria imagem que teve lugar em vários palcos da sociedade - do espaço palaciano à sessão académica - e, em última instância, na sua própria obra. Como acontece em qualquer processo de afirmação identitária, há que saber lidar com o olhar do outro, com a vertente da sanção pública - tanto a do grupo a que se deseja pertencer, como a de outros grupos com perfil vulgar -, razáo pela qual se recorre a determinados signos distintivos: indumentária, atitudes e reacçóes, ritos de sociabilidade, registos discursivos. O que torna, segundo pensamos, diferente o caso de D. Francisco Manuel é que nem tudo se resume a esse espectáculo de si, aberto para o exterior em busca de aplauso; na verdade, algo de substancial permanece. Desde logo, a conciliação entre um saber literário e cultural que só alguns estavam em condiçôes de manifestar com uma experiência de vida e de relacionamento social que lhe permitia descer bem fundo na anatomia do espírito humano. 
Quem se predispóe a percorrer, com certo grau de atenção, o conjunto da sua produçáo escrita - seja a que foi publicada, seja a que se conservou em estado manuscrito ou, em último caso até, a de que apenas temos conhecimento sumário -, depressa reconhece a sua extraordinária extensão e a sua profunda diversidade no que toca a temas, géneros e estilos. Boa parte dessa actividade responde, porém, a um propósito bem definido: o de estimular - quase sempre de acordo com a fórmula do ensinar deleitando - a perfeição ético-moral e intelectual do indivíduo, tanto no plano especulativo, como na dimensão prática, avivando assim o fosso que o separa da grande massa comum ou vulgar.

É todo um programa de pensamento e de acção que sem renegar por completo a lição dos humanistas a deseja superar, por ser outro o tempo, outro o sistema antropológico e outras as necessidades vitais que implica. Deste modo, movendo-se num espaço de reflexão que se mostra permeável a matrizes filosóficas e morais várias ou trilhando caminhos mais desviados, como o da observação satírica do estado do mundo - mas nem por isso menos eficazes no plano didáctico -, rara é a vez em que o autor perde de vista a vontade de ministrar um ensinamento útil. Com desconcertante ironia, uma ou outra vez confidenciava a sua perplexidade por se ver investido - e gostosamente aceitar - o papel de doutrinador, gizando modos de actuaçáo que deviam garantir a sobrevivência ou a reputação do indivíduo num mundo hostil, quando o caminho da sua vida mostrava que nem sempre soubera fazer valer, da melhor forma, esses seus atributos. Mas, seja como for, não se pode pôr em causa o seu empenho em promover valores e hábitos morais que deviam reger a acção humana em vários campos, do horizonte pessoal ao da comunidade entendida no seu todo, passando por uma escala intermédia que seria a da célula familiar.

Em face disto, é legítimo supor a presença de linhas de coerência que assegurem certo nível de unidade entre tanta diversidade de hábitos, comportamentos e ocupaçóes que o autor protagonizou ou sobre os quais criticamente reflectiu. Uma delas diz respeito, por certo, a tudo quanto se relaciona com o âmbito da prudência e da discrição, fazendo reflectir o peso de uma tradição doutrinal e de práticas de representaçáo bem enraizadas no terreno, sem que isso implique descartar a análise de outras categorias estéticas e sociológicas com manifesta relevância para a delimitação do horizonte da cortesania de Seiscentos. No fundo, o que aqui está em jogo é uma peculiar forma de ser e de estar no mundo - de ler o mundo - que dá origem a clivagens simbólicas de largo alcance no tecido social ${ }^{1}$.

Do limiar do governo de si, passando pelo âmbito familiar, até atingir o horizonte do governo do Estado, desenha-se um modelo virtual de esferas concêntricas que assentam em premissas comuns e obedecem a uma lógica de funcionamento similar, mas que, apesar da relativa autonomia, não podem ser separadas. Nesta ordem de ideias, ao príncipe, como vértice de um sistema social que se pretendia hierarquizado, e aos que eram chamados a exercer cargos públicos, pela posição saliente que nele ocupavam, exigiase que a regra da prudência se aplicasse tanto ao campo governativo, como ao familiar e individual. Visto do ângulo inverso, o modelo permite que cada esfera de nível inferior encontre na subsequente um ponto de referência em escala maior.

\footnotetext{
${ }^{1}$ Como procurámos demonstrar, de modo mais desenvolvido, na Dissertação de Doutoramento apresentada à Faculdade de Letras de Coimbra em 2008, sob o título de D. Francisco Manuel de Melo e o modelo do 'cortesão prudente e discreto' na cultura barroca peninsular.
} 
Deste modo, para o pensamento peninsular do Antigo Regime, a relevância da prudência - e de outros conceitos afins - não se restringia apenas ao domínio da actuação política, uma vez que também devia estar presente noutras esferas do governo humano. Dirigindo-se aos leitores da Carta de Guia de Casados, Paulo Craesbeeck, o impressor, aludia à clássica tripartição de saberes da Filosofia Moral em termos que aqui importa recuperar: «A ética cuida dos costumes do homem. A económica tem por fim o regimento das casas e famílias. A política entende sobre o governo das cidades, reinos e impérios; mas de tal maneira que a económica requere política e a política económica, porque o reino é casa grande e a casa reino pequeno; e a ética necessita da política e da económica, porque o homem é um mundo inteiro» ${ }^{2}$.

Sempre considerada de inestimável valor entre os pensadores e teólogos, ainda que a sua proeminência - ou até mesmo a sua presença - entre as outras virtudes não fosse matéria consensual, a prudência tornou-se decisiva numa sociedade táo conturbada como a do século XVII europeu. Abundante bibliografia tratava de reflectir sobre o alcance do comportamento prudencial e de pôr à disposição de potenciais interessados, e não necessariamente só dos mais novos ou dos recém-chegados ao selectivo ambiente palaciano, preceitos de carácter prático, em tom aforismático ou sob forma de avisos. D. Francisco Manuel, que bem conhecia a relevância pedagógica de tal tarefa, até porque dá corpo nalgumas de suas obras a intento semelhante, lembra que isso só por si não bastava, como pretenderiam alguns, para moldar um carácter prudente. Reduzir a prudência a uma «arte» ou a uma técnica, descrita sob forma racional e metódica, sem dar o devido valor à experiência pessoal que se adquire com o passar dos anos, com a prática da corte, com as viagens e com o relacionamento social, para só citar alguns campos relevantes, é ideia que não vinga no seu espírito ${ }^{3}$.

${ }^{2}$ Carta de Guia de Casados. Ed. Maria de Lurdes Correia Fernandes. Porto: Campo das Letras, 2003, p. 53. Numa das primeiras páginas de La Victoria del Hombre, procede, uma vez mais, à delimitação dessas três esferas da acção humana - a ética, que trata das acçôes do homem relativas a si próprio como indivíduo, a económica, que abrange as acçóes que têm por fim o bem da família, e a política, que se debruça sobre o bem dos homens reunidos em sociedade: «Esta [parte de la filosofía] es la que forma los filósofos más parecidos a hombres o los hombres más parecidos a filósofos, porque apurando su espíritu, en sus contemplaciones, los capacita para elevarse a las altísimas obras de la Naturaleza. Esta es la que amaestra los políticos, y les enseńa cómo deben gobernar a los estados, moderando sus pasiones y las ajenas. Esta fabrica los buenos padres de familias; porque modificando su inclinación con peso, y ejemplo, los instruye para que sin resabio del estrago, puedan dirigir sus hijos y mandar sus siervos: de tal suerte que nuestra moralidad es en la filosofía lo proprio que son en los edificios sus cimientos: donde pueden alabarse sus profesores que pretendiendo la Idea de un hombre cuerdo dibujan de un mesmo rasgo: un justo padre de familias, un sabio político, y un docto filósofo». (Obras morales de Don Francisco Manuel: parte primera [-segunda parte del primer tomo]. En Roma: por el Falco [por el Falco y Varesio], 1664, Vol. 1, pp. 2-3, sublinhado nosso). De modo semelhante, Francisco Barreda, em El mejor príncipe Trajano (Madrid, 1622), considera que «la humana prudencia tiene su oriente en la filosofía política, moral y económica. La política nos da luz para gobernar las ciudades, gentes y provincias. La moral, para moderar nuestros afectos y enderezar nuestras costumbres. La económica, para gozar en duración y en paz nuestras familias" (passo citado por Arturo del Hoyo na sua edição das Obras Completas de Baltasar Gracián y Morales, 3a ed. Madrid: Aguilar, 1967, p. 6n).

${ }^{3}$ Pela boca do Português, a primeira moeda a ter uso da palavra n' O Escritório Avarento e figura de incontestada autoridade sobre as demais, faz-se saber que «a doutrina dos dias é vagarosa mas firme. A muitos chega primeiro o aviso que a experiência. Mas eu nunca me fiei de juízos maduros por arte, porque sáo como ameixas mozinhas que, a poder de vinagre, vêm à fouce antes do tempo, perdendo o gosto, fermosura e saúde, de contado» (Apólogos 
Composta, de acordo com Cícero (De inventione, II, LIII), por três partes - memória, inteligência e providência (ou sagacidade) - a prudência apoia-se na experiência do passado para discernir e avaliar as circunstâncias presentes e deliberar sobre o que melhor convém a cada situação futura ${ }^{4}$. Por meio da memória, o homem prudente analisa assim a sua experiência e procura encontrar um registo de actuação que se adapte à circunstância que tem diante de si ou que possa estar iminente, tal como se pode ver em Mariana quando este afirma que «es la prudencia cierta prenda del ánimo en virtud de la cual mirando a todas partes, por la memoria de lo pasado, disponemos lo presente y prevenimos lo futuro, por lo que está ya claro y manifiesto rasgamos el velo de lo que está aún oculto y misterioso" ${ }^{5}$ ou em Saavedra Fajardo quando este descreve, na sua Idea de un príncipe político-cristiano representada en cien empresas ${ }^{6}$, a dimensão prudencial do governante por meio da expressão de cunho virgiliano "Quae sint, quae fuerint, quae mox ventura trahantur», retirada das Geórgicas, e apresenta um relógio de areia que se reflecte em dois espelhos como ilustração do tempo que flui, que se contempla no passado e se projecta no futuro.

É precisamente esta tríplice formulação que subjaz a muitas representaçóes iconográficas e emblemáticas da prudência ao longo da história da cultura ocidental. Assim, no célebre quadro Alegoria da Prudência, Ticiano retrata esta virtude cardeal por meio de três rostos masculinos - um velho cujo olhar se inclina para o lado esquerdo, um homem maduro ao centro e um jovem que olha para a direita - a que correspondem três figuras zoomórficas - um lobo, um leão e um cão - sendo o conjunto encimado pela legenda «Ex

Dialogais. Introdução, fixação de texto e notas de Pedro Serra, vol. II. Braga-Coimbra: Angelus Novus, 1999, p. 7). No que pode ser visto como crítica quer à minuciosa codificação de gestos e de atitudes, quer à galopante massificação de um saber que deveria ser privilégio só de alguns, escreve na Visita das Fontes: «Arrenego de perfeiçóes produzidas do artifício, e ainda de venturas que chegam por arte. Todas são como senhoria rogada, que nunca traz sabor perfeito" ( $A$ Visita das Fontes. Edição fac-similada e leitura do autógrafo, 1657, introdução e comentário por Giacinto Manuppella. Coimbra: Acta Universitatis Conimbrigensis, 1962, p. 57). Com especial acuidade nas suas obras de carácter histórico e moralístico, reconhece à experiência papel muito semelhante ao que Justo Lípsio - para não falar de outros pensadores e tratadistas - algumas décadas antes lhe estipulara nos Politicorum sive Civilis Doctrinae Libri Sex em termos de formação e de consolidação de um espírito prudente, uma vez que sem o conhecimento prático das coisas dificilmente se podia fazer valer os ensinamentos colhidos na cultura oral ou escrita que a tradição legara.

${ }^{4}$ Cabe aqui recordar a articulação que se estabelece entre a prudência e a sindérese: quando se pretende equacionar as formas concretas de realizar uma determinada acção é à prudência que se recorre, pois a sindérese, como vinculada que está aos primeiros princípios universais, não interfere no domínio da aplicação prática. Neste sentido, podemos dizer que as deliberações da prudência se prendem sempre com o hic et nunc, decorrem da realidade contingente, infinitamente vária, com que se confronta o indivíduo. Ao contrário dos ditames provindos da sindérese, que têm um carácter universal e evidente, o juízo da prudência não pode ser concebido fora das circunstâncias que rodeiam a própria decisão. Por tal motivo, São Tomás de Aquino (Summa theologiae, Ia-IIae, q. 57, art. 4.), retomando a liçáo aristotélica (Éthique à Nicomaque. Nouvelle traduction, avec introduction, notes et index de J. Tricot. Paris, 1987, VI, 5, 1140 b 20.), considera a prudência como sendo a recta razão (recta ratio agibilium) capaz de se ajustar aos actos contingentes da prática.

${ }^{5}$ Apud John C. Dowling, El pensamiento politico-filosófico de Saavedra Fajardo: posturas del siglo XVII ante la decadencia y conservación de monarquías. Murcia: Accademia 'Alfonso X El Sabio', 1957, p. 135.

${ }^{6}$ Diego de Saavedra Fajardo, Idea de un Príncipe Politico-Cristiano representada en cien empresas. Ed. de V. García de Diego, t. II. Madrid: Espasa-Calpe, 1958, pp. 30-31. 
praeteritio/ praesens prudenter agit/ in futuram actionem deturpet» («Pela experiência do passado, obra com prudência o presente para não deitar a perder a acção futura»). Cesare Ripa, por seu turno, em Iconologia (Pádua, Pietro Paolo Tozzi, 1611), representa-a com duas caras como se se tratasse de Jano, o rei sábio e prudente, mas ao incluir o reflexo de uma delas num espelho, reencontra a linha de figuração iconográfica que lhe atribuía, desde há muito, a tricefalia ${ }^{7}$. Foi, contudo, graças aos Emblemas de Alciato que determinados símbolos prudenciais, entre os quais se contava o rosto bifronte de Jano, numa versão mais simplificada do que a anterior pois só se faz menção dos planos do presente e do futuro (cfr. emblema XVIII, sob o título de "Prudentes»), alcançaram uma notável projecção na cultura europeia ${ }^{8}$.

A prudência, que já se contava entre as virtudes necessárias ao bom governo do príncipe na época medieval, como se pode ver pela tradição dos specula principis ${ }^{9}$, e que, nessa medida, já constituía um elemento essencial da actuação política, foi objecto de uma intensa codificação ao longo dos séculos XVI e XVII que tinha por fim adequá-la às novas circunstâncias do Estado e da sociedade. Por força das mutaçôes que entretanto tinham ocorrido, a política deixou de ser vista, na centúria de Seiscentos, apenas como saber que se debruçava sobre as formas de governo ou sobre a natureza do próprio poder, para passar a ser encarada cada vez mais como conhecimento dos meios através dos quais este se podia adquirir e, naturalmente, conservar. Com efeito, no que toca ao governo da república, a prudência política aparece, não raro, no pensamento hispânico, associada, quando não confundida, com a noção de «razão de Estado» ${ }^{10}$.

\footnotetext{
${ }^{7}$ Cesare Ripa, Iconologia overo Descrittione d'Imagini delle Virtù, Vitii, Affetti, Passioni humane, Corpi celesti, Mondo e sue parti [Pietro Paolo Tozzi, 1611], p. 441.

${ }^{8}$ É longo o rol de autores que, no âmbito hispânico, sob modulaçôes diversas mas partindo quase sempre de plataformas simbólicas e iconográficas fortemente enraizadas na tradição, se debruçaram sobre o tema da prudência, o que mostra a importância da emblemática na transmissão e inculcação de valores e formas de comportamento junto dos membros da aristocracia. Nos últimos anos, tem-se assistido a um interesse crescente por esta problemática, como fica provado pela publicação de numerosos estudos e ediçóes, de que destacamos Fernando R. De La Flor, Emblemas. Lecturas de la imagen simbólica (Madrid: 1995), o volume coordenado por S. López Poza, Literatura emblemática hispánica (Universidad de La Coruña, 1996), Antonio Bernat Vistarini e John T. Cull, Enciclopedia Akal de Emblemas Españoles Ilustrados (Madrid: Akal, 1999) e, de modo especial, Aurora Egido que em Las caras de la Prudencia y Baltasar Gracián (Madrid: Editorial Castalia, 2000) procura equacionar a repercussão que este tipo de produção cultural teve na obra do jesuíta aragonês.

${ }^{9}$ Este género que era, na origem, de matriz régia (tenhamos em mente Isócrates, Xenofonte e Díon Crisóstomo) tornou-se, com o tempo, objecto de uma atenção cada vez mais intensa por parte da nobreza europeia. Para isso muito terá contribuído o aparecimento de tratados com outro tipo de alcance, como é o caso do De Regimine Principum (c. 1287) de Egídio Romano e das obras que, de forma mais ou menos próxima, dele descendem, ou do Relox de Príncipes (1529) de Antonio de Guevara, que granjeou a admiraçáo dos cortesãos de Carlos V, que náo se contentam em fixar a imagem ideal do soberano, com o respectivo universo de valores, mas apontam práticas sociais e estabelecem normas de comportamento que se ajustam ao modus vivendi da aristocracia de corte. Como adverte Ana Isabel Buescu, em Imagens do príncipe. Discurso normativo e representação, 1525-49 (Lisboa: Cosmos, 1996) vários tratados ad usum delphini que exploram a vertente do ofício régio, mas que estabelecem também modelos de comportamento social, ainda que dirigidos ao soberano, adquirem um alcance mais vasto, pois servem tanto ao príncipe como aos indivíduos que gravitam em torno de si, os nobres que são parte integrante do círculo áulico.

${ }^{10}$ Segundo Barbosa Homem, mais não é do que «una doctrina especial, que por medio de varias reglas hace diestro a un Príncipe o para mantener en su propia persona los Estados que posee, o para conservar en los mismos
} 
Merece a pena determo-nos neste ponto, pois nem sempre, mesmo quando se encontrava salvaguardada a orientação católica contra-reformista, foi pacífica a utilização de um tal conceito, pela ambiguidade que suscitava. Temendo ser mal interpretado, Pedro Barbosa Homem sente a necessidade de distinguir a «Razão de Estado régia», que advoga, da "Razão de Estado tirânica», que atribui a Maquiavel e a todos quantos se inspiraram no seu pensamento. Às propostas do florentino, eivadas, segundo alguns, de irreligiosidade e de amoralismo, procuraram os escritores políticos do período barroco contrapor, na esteira do Giovanni Botero de Della Ragion di Stato, modelos de conduta política que náo pusessem em causa ou menosprezassem as orientaçóes da moral católica. Muitos foram os que tentaram responder ao desafio de conciliar, de modo harmonioso, o núcleo rígido de preceitos éticos e morais com as exigências reais da política ou, na expressão de Sousa Macedo, os «documentos divinos» com as "conveniências de estado" ${ }^{11}$, tendo em vista uma "política cristã»" ${ }^{12}$.

Dificultoso se torna falar da natureza e dos limites da prudência sem que a reflexáo sobre a prática da simulação e da dissimulação, e suas consequências éticas e morais, se não venha interpor. Se se pode considerar que a atenção que lhes é concedida por filósofos, moralistas e teólogos é anterior a Maquiavel, o certo é que foi com Il Principe que mais saliente se tornou a sua pregnância ideológica. Numa obra que a cada passo denuncia a insanável contradição entre a ética tradicional e a política, merece destaque o capítulo XVIII, em que se procura avaliar «de que modo têm os príncipes de manter a fé jurada», até pelo significativo caudal de comentários a que deu azo na cultura europeia ${ }^{13}$. Nele, abertamente recomendava que o príncipe, sempre que o interesse ou a conservação do Estado o exigisse, devia mentir, simular ou dissimular as suas verdadeiras intençóes. Perante a maldade intrínseca do ser humano, necessário se tornava «ser grande fingidor e dissimulador», até porque "aquele que engana sempre encontrará quem se deixe enganar»,

\footnotetext{
Estados la forma, y grandeza original que tienen, o para con nuevos aumentos ilustrar, o acrecentar la antígua masa de que ellos se forman». Este passo, que segue de perto a definição que Giovanni Botero apresenta no Livro I de Della Ragion di Stato, foi retirado de Discursos de la jurídica y verdadera Razón de Estado, formados sobre la vida y acciones del Rey don Juan el II, de buena memoria, Rey de Portugal llamado vulgarmente el Príncipe Perfecto. Contra Machavelo y Bodino, y los demás políticos de nuestros tiempos, sus sequazes, Coimbra, 1626, "Prefación general de toda la obra», art. I, presupuesto I, fl. 1v. (apud L. Reis Torgal e R. Longobardi Ralha, João Botero. Da Razão de Estado. Coimbra: INIC/Centro de História da Sociedade e da Cultura da U. de Coimbra, 1992, p. XX).

${ }^{11}$ Ambas figuram no título de uma obra que Sousa de Macedo consagrou ao tema, a Harmonia política dos documentos divinos com as conveniências d'Estado, estampada em 1661. Para uma abordagem mais aprofundada de obras que reflectem a preocupação de consolidar uma "política católica», é de grande utilidade a consulta de Ideologia Política e Teoria de Estado na Restauração (2 vols., Coimbra: Biblioteca Geral da Universidade, 19811982) de Reis Torgal.

${ }^{12}$ A expressão aparece com frequência em escritores peninsulares do século XVII a designar, como demonstra Maravall em La teoría española del Estado en el siglo XVII (Madrid: Instituto de Estudios Políticos, 1944, p. 367), o "conjunto de verdades que el esfuerzo discursivo de la razón, guiada y completada por la fe, nos da sobre el objeto de la política». Para este estado de coisas muito contribuiu a renovaçáo tomista em matéria de teologia, que teve lugar durante o período da Contra-Reforma, porque acentuou, como nunca até aí tinha acontecido, a relação de concordância entre fé e razão, as duas fontes de conhecimento que o indivíduo tinha ao seu dispor (pp. 365 e seg.).

${ }^{13}$ Nicolau Maquiavel, O Príncipe, tradução de Carlos E. de Soveral, 11ª ed. Lisboa: Guimarães Editores, 2003, cap. XVIII, pp. 83-87.
} 
redobrando assim o seu império sobre os outros. Sem outro critério de legitimação dos actos praticados que não o êxito político em prol da conservação e do fortalecimento do poder do Estado, é fácil reconhecer que tudo, incluindo a própria religião, se lhe devia sujeitar, razão pela qual encontravam os escritores e os responsáveis pelo aparelho ideológico que controlava as consciências, farta matéria para condenar as reflexốes do florentino ou dos que, de modo mais ou menos velado, lhe reconheciam validade.

Pela forma como muitos se aproximaram desse legado, ainda que por vezes a coberto de outras tradiçóes de pensamento - v.g. de inspiração tacitista -, ou como outros o pretendiam negar, por convicçáo própria ou em virtude de constrangimentos exteriores, se vê como condicionou o rumo da meditação não só política, mas ética e moral. Reflectindo a complexidade da matéria, nem sempre a dissimulação foi objecto de condenaçáo por parte de pensadores e moralistas da área católica. De facto, nalgumas situaçóes era tida como aceitável, e até legítima, contribuindo para flexibilizar a actuação do poder, mas sem nunca se confundir - apesar da similitude fónica - com a simulação, de pendor condenável, pelo seu vínculo a fins duvidosos. Apesar da ingratidão da tarefa, não são poucos os que procuram apurar a subtil linha de fronteira que separa a licitude do uso moralmente condenável, pondo em relevo o carácter defensivo da primeira ${ }^{14}$.

Desde as últimas décadas do século XVI, tinha-se tornado mais premente a procura de soluçôes eficazes para os problemas políticos, como bem documenta Justo Lípsio. Sabendo que a postura ingenuamente franca podia ter consequências nefastas na acção política, deixa em aberto, em Politicorum sive civilis doctrinae libri sex, a possibilidade de temperar a prudência com um ligeiro travo de dissimulação ou de fraude, se o fim a que se destina tal acção for honesto ${ }^{15}$. Que o escritor flamengo tinha noção do terreno instável que pisava é o que se deduz da clarificação que logo a seguir propóe. Sendo a fraude «un consejo agudo que se desvía de la virtud o de las leyes por bien del rey y su reino», pode comportar níveis distintos: ligeira, mediana e grande. À primeira modalidade, levemente tocada pela malícia, pertencem a desconfiança e a dissimulaçáo; a mediana encontra-se um pouco mais afastada da virtude, «llegando hasta los confines del vicio»; e a última, na sua radical ruptura com o comportamento virtuoso e com o espírito das leis, manifesta-se sob forma de perfídia e injustiça. Se a fraude ligeira é recomendada ao príncipe no seu trato com amigos e inimigos, a segunda só nalguns casos pode ser tolerada, ao passo que a terceira é liminarmente condenada ${ }^{16}$.

\footnotetext{
${ }^{14}$ Bastaria ter presente, a título de exemplo, a reflexão que Torquato Accetto desenvolve em Della dissimulazione onesta (a cura di Salvatore Silvano Nigro. Torino: Collana Biblioteca Einaudi n. 4, 1997).

${ }^{15}$ Sobre este aspecto, é digno de reparo o passo seguinte: «Aristóteles dice que los reinos se arruinan por el fraude y el engaño, pero no sería posible utilizar los mismos medios para lograr el fin opuesto, es decir, la salvación del reino? El vino no deja de serlo, aunque esté templado con un poco de agua; ni la prudencia prudencia si bien haya en ella algunas gotas de disimulación o fraude. Entendiendo que sea poco y a buen fin» (seguimos o texto pela tradução espanhola de Bernardino de Mendoza, Los seis libros de las politicas o doctrina civil de Justo Lipsio, que sirven para el gobierno del reinado o principado. Madrid: Juan Flamenco, 1604, cap. XIII, parte 4a).

${ }^{16}$ Lípsio tinha a seu favor o facto de combinar a erudição, bem patente nos trabalhos sobre autores clássicos, com o respeito pela piedade religiosa e uma arte de governaçáo que não se mostrava ofensiva para com os preceitos da religiáo católica, apesar dos tortuosos caminhos que por então trilhava a actividade política europeia.
} 
Percebe-se que a reflexão política se viu forçada com o tempo (não raro com choro e ranger de dentes) a descer do confortável pedestal teorético em que permanecera durante geraçóes, para enfrentar com outros olhos a realidade circundante, convertendo-se num saber historicizado. Ora, vendo-se forçado a viver - ou quem sabe de forma mais adequada, a sobreviver - num mundo de engano e de malícia, o indivíduo encontrava em procedimentos inspirados na astúcia e na dissimulação uma base mais segura. Sem que disto se possa fazer lei geral, porque cada posição doutrinária arrasta consigo implicaçóes próprias, torna-se óbvio que parte deste programa de actuaçáo podia ser tolerado se em causa estivesse um propósito defensivo, mas raramente o era se visasse intuito ofensivo ${ }^{17}$. Por outro lado, entre astúcia e prudência, pese embora uma ou outra similitude no que toca aos meios utilizados, intrometia-se sempre o problema da honestidade do fim a que visavam. Tudo isto decorria, como facilmente se deduz, de uma concepção moral do mundo e da humanidade de raiz pessimista, muito ligada à ideia de luta universal de uns contra os outros, mas que em todo o caso não aceitava a resignação e a passividade. Questáo que, por vezes, assaltava o espírito dos tratadistas políticos, e que revela a complexidade da matéria, era a de saber se o príncipe, e por extensão outros homens que desempenhavam funçóes governativas - à luz de uma certa relação de homologia -, quando confrontado(s) com uma actuação astuta e fraudulenta podia(m) ele(s) próprio(s) lançar mão da desconfiança e do recato, dissimulando os gestos e medindo as palavras, evitando assim cair em ingenuidade comprometedora. Por mais veemente que se revelasse a pregação moral neste campo, a prática encarregava-se de mostrar que nem sempre a verdade nua e crua podia levar a melhor, sendo por isso preferível saber ocultar e dissimular em ordem à defesa dos próprios interesses. De qualquer modo, para muitos, incluindo nesse número o caso de Gracián, cuja reflexão tem dado origem a leituras desencontradas (e, por vezes, desajustadas), o recurso a meios excepcionais como eram todos quantos requeriam alguma dose de artifício só se justificava por exigência das próprias circunstâncias.

Que a corte nem sempre era generosa com os justos, mas podia recompensar largamente os que conseguiam ganhar uma posição por meio da astúcia e conservá-la com base na prudência, sabiam-no tanto os seus mais assíduos e empenhados frequentadores, quanto os que conservavam a distância crítica suficiente para entender os mais secretos movimentos de tal universo. D. Francisco Manuel de Melo, sendo avesso a qualquer forma de manipulaçáo das emoçóes ou da expressáo do rosto, sobretudo quando na sua base se encontravam motivaçôes de carácter político ou de afirmação social, é natural que se insurgisse contra os

\footnotetext{
${ }^{17}$ Entre os peninsulares, sobretudo dos que se consagravam à instrução do príncipe, não menor é o desejo de clarificar os limites da dissimulação aceitável. Da insuspeita pena de Saavedra Fajardo surgem propostas de conciliação entre a moral e as condiçóes da acção política eficaz, mas sempre com o cuidado de exorcizar a sombra maquiavélica: segundo se inclina para o lado da auto-defesa ou para o do dano alheio, assim oscila o juízo de valor que sobre ela recai. Disso dá conta a Empresa XLIII de Idea de un Príncipe Político-Cristiano representada en cien empresas: "Alguna vez conviene encubrir la fuerza con la astucia, y la indignación con la benignidad, disimulando y acomodándose al tiempo y a las personas; se corona en esta empresa la frente del león, no con las artes de la raposa, viles y fraudulentas, indignas de la generosidad y corazón magnánimo del príncipe, sino con las sierpes, símbolo del Imperio y de la majestad prudente y vigilante, y jeroglífico en las Sagradas Letras de la prudencia; porque su astucia en defender la cabeza, en cerrar las orejas al encanto, y en las demás cosas, mira a su defensa propia, no al daño ajeno» (Ed. de V. García de Diego, t. I. Madrid: Espasa-Calpe, 1958, p. 404).
} 
que adoptavam tais procedimentos ${ }^{18}$. Sob formas diversas, e com um vigor a que pode não ser alheia a sua sobressaltada carreira cortesá, desenvolve uma fina hermenêutica do comportamento, pondo em realce os traços da natureza humana quando em acesa disputa pela sobrevivência num espaço tão competitivo. Longe de ser uma questão marginal no quadro das relaçôes humanas, o controle das emoçôes, ora como instrumento de defesa, ora como meio de obtenção de posiçôes vantajosas, deixou rastro profundo.

Olhando em seu redor, o autor mais depressa vê as máscaras da virtude do que o seu verdadeiro rosto, pelo que o exercício de descortinar a verdadeira essência das coisas se não está fatalmente condenado ao fracasso, só com dificuldade poderá subsistir num mundo que a si próprio se concebe como teatro. Por estar dependente da face mais visível e das ilusóes que a cobrem, a verdade torna-se contingente e alvo de sistemática manipulação por parte dos actores sociais ${ }^{19}$.

Ver e ser visto, dissimular para melhor controlar o jogo social ou simular para reduzir a margem de manobra dos adversários são vectores que concorrem para o reconhecimento de uma realidade subjugada pelas aparências ${ }^{20}$. Nem sempre é possível saber ao certo se ao manifestar posiçóes desta índole estaria a pensar em casos concretos de literatura curial ou se a sua análise resultava só de observação directa. Mesmo tendo bem presente as contingências do universo empírico em que decorria a acção política, o autor nunca desistiu da pretensão de nele ver reflectidos princípios de carácter ético ou religioso. No complexo quadro de doutrinas de inspiração vária (anti-maquiavelista, tacitista, antitacitista, senequista, para não adensar mais o elenco de categorias que muitas vezes até apareciam imbricadas), era voz corrente que os ímpios adeptos da falsa «razão de Estado» (Maquiavel, seu principal inspirador, Bodin e outros escritores protestantes franceses, que formavam no entender de Gracián «una confitada inmundicia de vicios y de pecados:

${ }^{18}$ Em El Fenis de Africa Agustino Aurelio Obispo Hypponense pode ler-se: «Ya ninguno despliega sin arte los labios delante de su señor. Hasta las pestańas, los parpados, y las nińas de los ojos, se mueven por tropos de su fingida política; los pasos, los movimientos, son figuras artificiales; en fin toda la vida de los recientes cortesanos es una retorica declamación; por eso tan declamada" (Obras Morales, Vol. 2, p. 133).

${ }^{19}$ Observava Apolo, n'A Visita das Fontes, a propósito de certo pretendente que desejava exercer o ofício de governante que "os antigos disseram que a necessidade era mestra das cousas; eu antes creio que o apetite, agora vestido de ambição, agora de zelo, agora de interesse, porque os mais dos afectos humanos mudam de trajo cada dia» (Edição fac-similada e leitura do autógrafo, 1657, introdução e comentário por Giacinto Manuppella. Coimbra: Acta Universitatis Conimbrigensis, 1962, p. 55). Com desarmante ironia, há-de explicar a Fonte Nova, neste mesmo apólogo, que a presença do simulacro é sinal do apreço que ainda suscita o original, mesmo não sendo actualizado: «o mundo não está de todo depravado, enquanto vejo durar a hipocrisia. Esse fingimento de virtude ainda nos dá algum sinal de que ela pode valer algũa cousa» (Id., ibid., p. 85).

${ }^{20}$ Seguramente nenhum outro escritor barroco compreendeu tão bem como Baltasar Gracián esse estado de coisas e forneceu aos seus leitores os meios para daí tirar o máximo partido. Entre os muitos lugares da sua obra que reflectem o peso dessa dialéctica entre interior e exterior, com apelo à sua sábia manipulação, conta-se um passo do realce XXII do Discreto em que se reconhece que «lo primero con que topamos no son las esencias de las cosas, sino las apariencias; por lo exterior se viene en conocimiento de lo interior, y por la corteza del trato sacamos el fruto del caudal; que aun a la persona que no conocemos por el porte la juzgamos» (Obras Completas de Baltasar Gracián y Morales, $3^{a}$ ed. Madrid: Aguilar, 1967, p. 137). Sabendo que na prática assim podia suceder, pois nem todos os homens são "iguais no valor como o são no parecer», Melo prefere alertar os seus leitores, redobrando a capacidade defensiva, a lançar mão dos artifícios que o jesuíta com maior pragmatismo aconselhava. 
razones, no de Estado, sino de establo») eram conhecedores exímios dos recursos da simulação, que não hesitavam em aproveitar para poderem atingir os seus fins ${ }^{21}$.

A precisão e a elegância dos gestos, num esforço premeditado de auto-controle e de absoluto respeito pela etiqueta, levava a sufocar por inteiro a expressáo natural e, por conseguinte, a destruir qualquer possibilidade de transparência nas relaçóes sociais, facto que alguns moralistas da época não se cansaram de zurzir e que escritores do século XVIII, como Rousseau, severamente condenaram. Operando, no quadro de disputa pelo favor do príncipe, como máscara de ambiçóes pessoais, a cortesia servia para causar uma impressão favorável - enquanto «art de plaire à la cour», parafraseando o título de Nicolas Faret ${ }^{22}$-, reforçando a reputação do cortesão. Em si, a tendência para agradar não pode ser considerada como defeito, mas a prática mostrou que era, pela capacidade de adaptação da aparência às circunstâncias e aos interlocutores, objecto de metamorfoses fraudulentas. Do ponto de vista moral, a questão era delicada, pois a partir do momento em que as qualidades do indivíduo se apresentam mais como competências que permitem alcançar o êxito na interacçáo social do que como virtudes, significa que podem ser usadas para o bem ou para o mal.

A preocupação eticista que sempre demonstra não o impede de ver as adversas condiçóes que a realidade punha diante dos olhos dos que tinham que negociar ou desempenhar uma missão política. $\mathrm{Na}$ verdade, o desafio consistia em articular um discurso ético capaz de suportar o embate com os novos problemas com que se deparava a sociedade e não apenas em repisar preceitos que a ordem moral tradicional divulgava: para ele, organizar um corpo discursivo a partir de conselhos, advertências ou exemplos colhidos nos textos bíblicos, pondo em realce as tão divulgadas virtudes cristológicas da sabedoria, justiça e prudência, não era por certo a estratégia mais adequada para fazer face ao avanço de doutrinas de teor mais "subversivo»" Por mais ágeis que alguns se mostrassem no manejo de fontes clássicas e medievais, quantas vezes de modo reverencial, se não compreendessem o mundo novo que se apresentava diante dos seus olhos - mundo

\footnotetext{
${ }^{21}$ Acreditamos que Melo opera, na maior parte dos casos, sob o signo de um sincretismo (ainda quando não explicitamente assumido), mas sempre com o propósito de oferecer aos seus leitores um modelo de ética que se mostre capaz de guiar o agir humano e em conformidade com os dogmas da religiáo que professa. Sem pôr em causa a indiscutível relevância dos filósofos «antigos» (ou dos "primeiros sábios»), até porque da sua lição muito beneficiou, sentia que era possível articular certos aspectos da história do pensamento ocidental com as exigências da vida cristá. Na verdade, quer seja pela utilizaçáo de exempla colhidos em obras que se filiam nesta doutrina, quer pela glosa de temas ou de tópicos com evidente afinidade entre si, como o do desprezo dos falsos bens, abrese espaço a um intenso e frutuoso acolhimento.

${ }^{22}$ L' honnête homme ou l' art de plaire à la cour, ed. de Maurice Magendie. Paris: PUF, 1925 (Genève: Slatkine Reprints, 1970).

${ }^{23}$ Sirva de exemplo o seguinte passo: «Aqueles autores que universalmente ensinam, não importa que sejam antigos, antes porventura são melhores, porque nas primeiras idades do mundo, dado que as ciências não estivessem tão descobertas nos mestres, estava mais pura a aptidão nos discípulos. Porém, aqueles que especialmente nos ensinam sobre pontos determinados, é bem que sejam modernos, ou porque esses resolvem já as dúvidas opostas da malícia ou porque, sendo mais vizinhos a nós, se conformam com os nossos usos e praticam os remédios da sua corrupção" (Le dialogue 'Hospital das Letras' de D. Francisco Manuel de Melo. Texte établi d'après l'édition princeps et les manuscrits, variantes et notes por Jean Colomès. Paris: Fundação Calouste Gulbenkian - Centro Cultural Português, 1970, p. 123).
} 
de permanente milícia contra a malícia do homem, segundo o aforismo XIII do Oráculo ou em que «a malícia é mais longa que a arte», pois se estende "quase incompreensìvelmente», na versão de Melo -, de pouco adiantava a sua reflexão ${ }^{24}$.

Para além da adequação às circunstâncias de cada lugar e tempo, uma vez que os modelos abstractamente compostos já se tinham revelado ineficazes para compreender o real e para poder intervir sobre ele, sobressai a vertente da experiência. Adquirida no exercício de funçóes de carácter governativo e reforçada pelo saber colhido em obras históricas, que guardavam memória de factos notáveis e de perigosos desmandos, constituía para muitos caminho seguro para alcançar a tão ambicionada prudência política. Especial significado tinha este facto para D. Francisco que acumulou, pese embora as contrariedades sofridas, experiência neste campo, manifestando por isso uma visão distinta dos que reflectiam sobre uma realidade que nunca chegaram a conhecer ${ }^{25}$.

Valendo-se da autoridade de um sábio que não chega a nomear (talvez o Aristóteles de Ética), Lípsio, no Hospital das Letras, insiste que «a dominação dos homens exercitada dos príncipes é a mais suma arte das artes e a ciência das ciências» ${ }^{26}$. Com maior vigor do que alguma vez até então tinha acontecido, no século XVII os escritores, ora condicionados por preocupaçóes éticas e religiosas, ora mais abertos ao horizonte empírico, compreenderam a urgência de encarar o governo do Estado como uma ciência ou arte. Questáo delicada, e amplamente debatida, esta de saber se era ou náo possível propor um método rigoroso para alcançar o saber político. Pelo que se conhece do seu pensamento, percebe-se que se aveio mal com regras de actuação de sentido universal e transtemporal, pelo que não estaria por certo no seu horizonte a defesa de uma filosofia política tão rígida. Mudando os tempos e as circunstâncias, sendo diferente a qualidade dos sujeitos, só com muita cautela se podia aplicar a liçáo do passado. O seu intento era, pois, outro: mostrar que a prudência governativa não dependia só de puro esforço especulativo e que o grau de exigência, no campo da acçáo, tinha aumentado de modo considerável.

Como mostruário das doutrinas do tempo, o Hospital das Letras dificilmente podia fugir à consideração do tacitismo e do maquiavelismo, bem como à controvérsia que em

${ }^{24}$ Hospital das Letras, p. 115. Convém nunca perder de vista que a sua reflexão deve ser lida à luz de um horizonte epocal profundamente marcado por tensôes, muitas vezes insanáveis, entre práticas e valores com tradição multissecular e exigências palpáveis de um mundo em acelerada transformação, entre sectores sociais em crise, que viam a sua preponderância ameaçada, e novas figuras emergentes.

${ }^{25}$ Ainda que não fosse condição sine qua non para elaborar obra de valia, aceita-se que o estatuto de homem de corte, pela assídua convivência com os dilemas e problemas que surgiam no âmbito do poder, propiciasse uma posição de análise e de doutrinação mais favorável. Em boa medida por aí passa, aliás, a justificação ideológica que o Hospital avança, pois «os que tão apertadamente impóem leis sobre o governo comum das repúblicas faltam na arte prática delas» e se é desejável que "as cidades observem leis justas», também "é necessário considerar a diferença que vai de uma cidade a um convento". Sem nunca ter chegado a elaborar um espelho de príncipes, enquanto corpo doutrinal unitário e coeso, a verdade é que em vários pontos da sua obra reflecte sobre matéria relevante a esse nível, ora detendo-se sobre a formação dos que viriam a ocupar tal cargo, ora sondando os caminhos da governação, para já não falar dos juízos de valor sobre o mérito intrínseco de obras (sobretudo peninsulares) que compunham essa larga tradição cultural. Muito do que se prescrevia ao homem que tinha a seu cargo o comando do reino também se podia aplicar ao varão nobre e vice-versa, num movimento pendular carregado de sentido, mas seria arriscado menosprezar, como sucedia na pena de alguns, a especificidade própria daquela função.

${ }^{26}$ Hospital das Letras, p. 127. 
seu torno se gerou, por ser o espelho das tensões que afectavam o agir das elites sociais. Em termos peninsulares - e julgamos ser este o enquadramento mais viável, dado o nível de imbricação cultural existente -, o processo de recepção de Tácito e a formação do tacitismo como corrente de pensamento político são fenómenos convergentes no plano temporal, embora não devam ser confundidos. É certo que muitos pensadores do século XVII viam o historiador latino, acima de tudo, através da lente dos partidários desta corrente (como se deduz do epíteto com que Melo o crisma: "patriarca dos estadistas»), mas a verdade é que esta não se esgotava apenas no autor dos Anais, por mais significativo que fosse, uma vez que assimilava também contributos de áreas como o maquiavelismo, o senequismo e o neoestoicismo, ou até mesmo o cristianismo e o erasmismo. Com verosimilitude histórica, cabe a Lípsio (o responsável pela mais proveitosa via de penetração do tacitismo em solo peninsular) a defesa do autor latino contra os ataques ou recriminaçóes que as outras personagens lhe dirigem.

Contra a opiniáo de alguns, acredita Melo que a reflexáo sobre questôes de ética e de moral deve figurar em lugar proeminente entre os saberes do cortesáo. Não pretende suprimir matérias que, numa perspectiva utilitária, de modo mais próximo se relacionam com o horizonte da corte, antes agregar uma dimensão que confere maior profundidade (ou sentido de rectidão) à actividade cortesã. Talvez por isso mesmo alargado se mostre o espectro sociológico do público que se espera possa vir a ler uma obra de carácter moral como El fenis de Africa Agustino Aurelio Obispo Hypponense, sobretudo se se tiver em conta que, de acordo com os ditames da discriçáo, repousa sobre o leitor a responsabilidade de levar mais longe a reflexão que a entidade autoral ajudou a estimular, como se alude na «Carta» proemial»: «Al cortesano, al letrado, al piedoso, y también al crítico, mi libro a todos llama. [...] Al deleite, y a la doctrina, se escribe; si acaso aquí lo hallases todo, que te falta? [...] Yo no escribo a comunes; por eso no escribo comúnmente. Advierte que quanto yo menos dijere, tú serás el que más hayas entendido. Tú eres el discreto; yo solo apunto donde lo seas. [...] La moralidad, de suyo melencolica, pide un hablar aseado, y breve, no con vulgar discurso ${ }^{27}$. De uma escrita que se quer discreta náo se espera um aglomerado de indicaçóes minuciosas sobre o comportamento a seguir nas mais diversas situaçôes do quotidiano com que se depara o cortesão peninsular, antes a lei geral que cada um saberá adaptar às circunstâncias específicas de cada momento.

Salvo pontuais excepçôes, algumas muito recentes e de preciosa utilidade, outras mais antigas e quase por inteiro centradas sobre a obra do jesuíta aragonês, é forçoso admitir que o paradigma da discriçáo que tanto peso teve na cultura peninsular do Antigo Regime, quer na sua valência ético-social, quer estética, não tem merecido por parte da crítica a devida atençãa ${ }^{28}$. Por outro lado, muito embora tenha funcionado, ao longo de

${ }^{27}$ Obras Morales de Don Francisco Manuel. Roma: Falco y Varesio, 1664, vol. II.

${ }^{28}$ Permitimo-nos destacar alguns estudos de inquestionável valia neste campo: João Adolfo Hansen, "Discreto/vulgar: modelos culturais nas práticas de representaçáo barroca», in Estudos Portugueses e Africanos, Campinas, n. ${ }^{\circ}$ 17, 1991, pp. $29-57$ e "O Discreto", in A. Novaes (org.), Libertinos, libertários. Sáo Paulo: Companhia das Letras, 1996; A. Álvarez-Ossorio Alvariño, «El Cortesano Discreto: itinerario de ciencia áulica (ss. XVI-XVII)", Historia Social, 28 (1997), pp. 73-94 (numa versão mais ampliada: "Corte y cortesanos en la Monarquía de España», in G. Patrizi e A. Quondam (coord.), Educare il corpo, educare la parola nella trattatistica del 
um arco temporal que vai dos últimos decénios do século XVI até pelo menos meados do século XVIII, em regime de recíproca implicação com a prudência, o seu peso específico no âmbito da tratadística é muito menor. Enquanto ponto nodal do sistema de virtudes, ou até como virtude política por excelência, como sinónimo de "razão de Estado», para não referir outros campos de aplicação, compreende-se que aquela pudesse suscitar uma quantiosa e constante reflexão, mas nada parece justificar o relativo descuido de escritores e pensadores da época em apurar, com certo grau de rigor conceptual, o seu alcance e os modos por que se manifesta. O impressivo grau de ocorrência dos termos «discreto» e «discrição" (e de seus derivados) em textos de cariz literário e não só, bem como a pregnância ideológica que se lhes reconhece, não teve tradução directa em termos de sistematização teórica. Talvez se possa encontrar uma razão de fundo para esta situação na desconfiança com que uma parte da nobreza peninsular olhava para certa literatura áulica que punha à disposição de um público alargado preceitos que em tempos mais recuados eram pertença exclusiva de um núcleo social privilegiado. Em todo o caso, vale a pena notar que há toda uma série de termos e de expressóes (prudente; discreto; sábio; entendido; cuerdo...) que, conservando embora predicados próprios, remetem, em última análise, para um mesmo arquétipo de virtude e de excelência que, pela sua intrínseca raridade, se torna marca diferencial.

Para além do trabalho seminal de Gracián, El Discreto, cuja fortuna editorial e crítica não chega ainda assim a rivalizar com outros marcos da sua produção literária, mas que claramente se destaca nesta pouco povoada floresta, é de justiça lembrar o Diálogo de la discreción de Damasio de Frías y Balboa, escrito cerca de 1579 e apenas publicado na segunda década do século XX. O que, de momento, nos interessa considerar nesse texto das últimas décadas de Quinhentos é tâo-só o modo como o seu autor, e provavelmente o círculo cortesão de que fazia parte, encarava a discrição. De facto, com Frías, Cervantes, e mais ainda com Gracián pela singularidade do seu esforço, tomou forma um movimento de secularização que, sem rasurar por completo a carga teológico-doutrinal que a tradição patrística lhe atribuíra, como se pode ver pela obra de um Calderón de la Barca em pleno século XVII (v.g. El gran teatro del mundo), lhe incutiu novo fôlego. Se o esforço especulativo de Frías, apesar da sua pontual aridez escolasticista, não merece ser desprezado, o certo é que só com Gracián o método expositivo, pela viveza e sublime rasgo das estratégias perfilhadas, se aproxima dos atributos do próprio objecto que se pretende definir. Assim, por mais próximos que se afigurem, no plano doutrinal, os postulados de que ambos partem, separa-os a leveza (e a modernidade, de algum modo) da expressão que o jesuíta manifesta nos seus textos e que constituía, já de si, um estímulo para uma nova abordagem do mundo e da vida. A variedade genológica, com distinta função pragmática, e as formas elocutivas que o pequeno tratado exibe (emblemas, sátiras, apólogos, sentenças, apotegmas), motivo de perplexidade durante largo tempo para uma comunidade

\footnotetext{
Rinascimento. Roma: Bulzoni, 1998, pp. 297-365); «El laberinto de la corte. La imagen del cortesano durante el reinado de Felipe II", in Felipe II. Un monarca y su época. Las tierras y los hombres del rey, Catálogo de la Exposición celebrada en el palacio de Villena. Valladolid: 22 de Outubro de 1998 - 10 de Janeiro de 1999, Sociedad Estatal para la Conmemoración de los Centenarios de Felipe II y Carlos V, 1998; "La discreción del cortesano", Edad de Oro, XVIII (1999), pp. 9-45.
} 
crítica que não alcançava a sua beleza intrínseca, são hoje vistas como um dos seus mais impressivos traços.

Uma leitura «discreta» da realidade, seja a que imediatamente se depara ao indivíduo, seja a que lhe é apresentada de forma mediata pela voz ou pela pena de uma instância exterior, pressupóe sempre capacidade de discernimento. Nada repugna mais do que a figura de um destinatário que passivamente aceita o que lhe é imposto, pois com isso se destrói a base da discrição. A título de exemplo, o que levou Melo ou Gracián, para não citar outros, a manifestarem certa repulsa pelos manuais de civilidade compostos à maneira de Il Galateo, não foi seguramente o facto de discordarem da bondade da matéria, mas do modo impositivo e pouco estimulante (no conturbado tempo histórico que era o deles) como pretendiam chegar até aos seus leitores. É que a construção do saber deve ser de ordem dinâmica e interactiva, pelo que ao leitor cabe penetrar no mais recôndito dessa doutrina que se manifesta por entre os meandros da agudeza mental e verbal. O ciclo completa-se depois quando se mostra capaz de aplicá-la a casos concretos, acomodando o que assimilou a contextos bem diversos do original.

Importa, pois, notar que, no plano estritamente individual, a prudência, coadjuvada pela discrição, poderiam assegurar ao frequentador dos ambientes áulicos e dos círculos cortesãos, espaços onde imperava uma competitividade feroz, a protecção necessária contra manobras que o pudessem derrubar ou dificultar a sua ascensão e aumento de prestígio. Com base nesses valores, os tratadistas áulicos procuraram esboçar um esquema de acção que permitisse sobreviver aos golpes da Fortuna, «aquella reina tan soberana, inscrutable, inexorable, risueña con unos, esquiva con otros, ya madre, ya madrastra, no por pasión, sí por la arcanidad de inaccesibles juicios», para usar palavras de Gracián ${ }^{29}$, e fazer prevalecer, na medida do possível, a sua vontade no mundo hostil em que vivia.

Fazia parte da natureza mesma do cortesão que percorria os corredores dos centros de poder em território peninsular, segundo se deduz de bom número de testemunhos que sobreviveram ao passar dos séculos, uma permanente insatisfação e, não raro, um desencanto profundo. $\mathrm{Na}$ raiz de uma tal situaçáo podemos encontrar razóes que se prendem com o próprio modelo de organização política e com a estrutura da sociedade então prevalecentes, que tornavam cada vez mais exigentes os esforços desenvolvidos no sentido de assegurar a conservaçáo do estatuto adquirido ou de promover a conquista de uma posiçáo mais vantajosa na complexa hierarquia de corte. Tudo isso pressupunha a aquisição de atributos, de saberes e de competências, com destaque para a prudência e a discrição, que tanto podiam granjear as atençôes da comunidade cortesâ, como tirar partido da relação com os mais poderosos, os únicos capazes de dispensar benesses. Ainda assim, como bem atesta o trajecto vivencial de Melo, era forçoso, por vezes, lutar contra adversidades mais graves, pelo que foi ganhando expressão na cultura política (e não só) do tempo um lastro de persistente desengano com propósito defensivo. Não se pode esquecer que a construção do seu discurso político-moral, moldado a partir dos valores consagrados pela dinâmica contra-reformista e pelo absolutismo monárquico-senhorial, ocorre num tempo de profunda instabilidade e de vincada crise axiológica. À força de

\footnotetext{
${ }^{29}$ El Héroe, Obras Completas, ed. cit., p. 20.
} 
tantos dissabores sofridos, desenvolveu a capacidade de desvelar, por entre sombras e quimeras, o verdadeiro rosto do real, razão pela qual assistimos em vários passos da sua obra à desmontagem da densa trama de interesses e de paixóes que subjaz à vivência social.

Meditando sobre os sucessos e insucessos da experiência de corte e da prática política (da sua, de amigos e companheiros de jornada ou de outros homens públicos), é natural que fizesse valer um olhar desencantado sobre o mundo em seu redor. Ainda que não se possa negar o peso efectivo que o incumprimento de um certo cursus honorum, para o qual se sentia (e estava, de facto) preparado, teve em todo este processo, o certo é que as suas raízes tocam mais fundo, pois só esse estado de lucidez (mais do que de abatimento, como se podia supor à vista desarmada) capacita o homem para saborear o verdadeiro contentamento, o que o espera num horizonte superior e eterno. Ao contrário de outras visóes do sentir prudente e discreto, que ora tendiam a acentuar o imediatismo da acçáo prática, ora o fascínio da exibição pública, a sua implicava também calcorrear um caminho de virtude cujo termo coincidia com a Salvação.

Levada às últimas consequências, uma arte da prudência e da discrição é em grande medida (se náo antes de tudo o mais) uma arte de bem saber morrer. $\mathrm{O}$ lance pode parecer forçado a um primeiro olhar, mas deixará de o ser se tivermos em mente que as últimas linhas de El Discreto são muito a propósito dedicadas à derradeira etapa da existência. Depois de evocar uma série de exercícios que devem pontuar a «culta repartición de la vida de un discreto", termina reconhecendo que é «corona de la discreción el saber filosofar, sacando de todo, como solícita abeja, o la miel del gustoso provecho o la cera para la luz del desengaño. La misma Filosofía no es otro que meditación de la muerte; que es menester meditarla muchas veces antes, para acertarla hacer bien una sola después ${ }^{30}$. Ora, o que assim se pretende provar, na linha da instrução moral que visa preparar o momento da morte, é que o fruto a colher nessa outra vida há-de resultar do esforço dispendido ou, seguindo o trilho metafórico do texto, da sábia utilização do tempo em sede terrena. Se se tomar como verdadeiro o axioma que estipulava que «não há cousa que não tenha sua hora no mundo", ou em clave mais quevediana, o «estatuto da hora de todos e de tudo», então não há razão para descurar as obrigaçôes éticas e morais, em favor de soluções mais sedutoras $^{31}$. O propósito é claro: esquecidos da vertiginosa passagem do tempo, os homens «reservam todas [as horas] para si a fim de as dispenderem, vãmente, em seus passatempos», concedendo apenas a Deus "a hora de sua morte», num gesto de dilapidação de um bem que é, por natureza, escasso. Desta forma, compreende-se que, aos olhos do desenganado Relógio da Cidade, a sabedoria, enquanto equivalente a rectidão moral, exija reflectir sobre a «infalibilidade da hora que está esperando [cada vivente], como hora sua», de modo a que esta não o surpreenda, nem ele tão-pouco a tema ${ }^{32}$.

${ }^{30}$ El Discreto, O.C., p. 147. Se se recuar um pouco no tempo já se pode encontrar no título de um dos ensaios de Montaigne (I, 20) uma expressão, moldada ao que tudo indica sobre uma referência de Cícero (mas que também náo anda longe do pensamento de Séneca em De brevitate vitae, 7, 3: "quod magis fortasse miraberis, tota uita discendum est mori»): Que philosopher, c'est apprendre à mourir.

${ }^{31}$ Cfr. Os Relógios Falantes, p. 29.

32 Os Relógios Falantes, p. 28. 
Mesmo admitindo que a corte, a um tempo lugar de afirmação da ordem e da sacralidade, ambiente competitivo e arriscado, cenário de luz e de sombra, constituía o ponto nuclear da existência da gente ilustre e generosa, muito limitada ficaria qualquer abordagem que apenas a ela se restringisse, quando é sabido que outras instâncias (quer do foro privado, quer da esfera pública) tanto pesam tinham na modelação dos comportamentos. A título de exemplo, à Carta de Guia de Casados, com os seus ensinamentos em matéria de vida conjugal e de gestão do espaço familiar, caberia manifestar um modelo de prudência doméstica, mediante o qual o membro mais destacado desse «reino pequeno» pudesse garantir o bem comum dos seus parentes e criados. $\mathrm{Na}$ prática, promovia o conhecimento e a aplicação de certos instrumentos de acção "para que - e são palavras suas, que figuram logo no título que encabeça o tratado - pelo caminho da prudência se acerte com a casa do descanso" ${ }^{33}$.

Por outro lado, fazendo convergir o efeito da doutrinação aplicada ao campo militar e a metódica observação da experiência própria e alheia que se faz sentir em tantos textos seus (sobretudo de natureza historiográfica), torna-se possível seguir o rasto da prudência até um domínio de estratégica importância para o sector nobiliárquico e verificar que esta se tornou objecto de cuidadosa avaliação por parte da entidade autoral. Nessa medida, compreende-se que tenha invocado, com desusada insistência, a sua condição de observador privilegiado do curso dos acontecimentos que narra, pois com isso conseguia amplificar o alcance da lição proveitosa que pretendia fazer passar, como se pode comprovar pela leitura de Epanáforas de Vária História Portuguesa ou da Historia de los movimientos, separación y guerra de Cataluña ${ }^{34}$. Em registo elogioso ou com manifesto poder censório, se a ocasião assim o exigia ${ }^{35}$, compôs o retrato de figuras, reais ou ficcionais, que em face de determinadas circunstâncias eram chamadas a pôr à prova a sua capacidade de discernimento, avançando não raro para a extrapolação de sentidos gerais e de aplicação universal ${ }^{36}$.

${ }^{33}$ Carta de Guia de Casados, p. 49.

${ }^{34}$ Epanáforas de Vária História Portuguesa, introdução e apêndice documental por Joel Serrão. Lisboa: Imprensa Nacional-Casa da Moeda, s.d. [1977]. Reproduçâo fac-similada da ed. de 1660 ou a Historia de los movimientos, separación y guerra de Cataluña, edición, introducción y notas de Joan Estruch Tobella. Madrid: Clásicos Castalia, 1996.

${ }^{35}$ É de salientar o cuidado com que nomeia os atentados, por meio de actos e deliberaçōes, contra o que considera ser uma actuaçáo prudente. Assim, com a frieza e o distanciamento que só o tempo sabe proporcionar, o narrador de Conflito do Canal há-de contestar, por exemplo, a precipitação e a impulsividade que tolheram o espírito do general Oquendo nos instantes mais decisivos (cfr. Conflito do Canal de Inglaterra entre as armas espanholas e holandesas. Ano 1639. Epanáfora Bélica, in Epanáforas de Vária História Portuguesa, ed. cit., 1977, pp. 409 e 415).

${ }^{36}$ À semelhança de um Giovanni Botero, fazia depender a «excelência nas armas» da harmoniosa conjugaçáo de prudência e valor, com prevalência do primeiro termo. Podemos até dizer, no que toca ao português, que se trata de convicção profundamente enraizada no seu espírito, uma vez que se manifesta com vigor em vários momentos da sua frutuosa carreira de escritor. A título de exemplo, considere-se o que diz na carta-dedicatória da Epanáfora Política, de 4 de Setembro de 1649, sobre as virtudes do seu homenageado (que não chega a identificar): «sendo-vos táo familiares na guerra e na paz, como capitáo e como ministro; emprendendo, ou suportando, que são os dous polos (valor e prudência) sobre os quais se resolve a esfera máxima dos varóes grandes» (Epanáforas de vária história portuguesa, pp. 1-2). 
A um outro nível, e na sequência do que vinha sendo proposto por certos manuais de comportamento social ou por obras poéticas e ficcionais (que, não raro, até mostravam ser mais eficientes em matéria de circulaçáo de ideias e de concepçóes de vida), o horizonte da milícia era visto - depois de descartado, como é óbvio, o impacto mais sangrento que o confronto bélico sempre acarretava - como prolongamento do espaço de formaçáo e de actualização de hábitos cortesãos. Sublinhe-se a necessidade, sentida por Melo e por outros membros do sector nobiliárquico, de assegurar e se possível alargar, nesse quadro de acentuada movência social que por então se vivia, um grau de prestígio que se encontrava ameaçado, lançando mão de cuidadosa encenação de gestos e atitudes de destacados chefes militares.

Enquanto abóbada deste edifício da discrição de matriz peninsular, concedia-se amplo espaço, em numerosas obras, ao louvor dos dotes intelectuais do indivíduo. Com a sua finura habitual, resumia Gracián esse alcance nobilitante do saber no axioma «No vive vida de hombre sino el que sabe» ${ }^{37}$. Já para Manuel de Melo, como se reitera no "Aparato a los lectores» das Obras Morales, constando o mundo de doutos e néscios, mas sendo mais impressivo o número dos últimos, é crucial que esses poucos indivíduos de cunho elitista, «que siguen el amor de la sabiduría, trabajen mucho más en su defensa y beneficio, porque no llegue a ser suprimida de la indiscrición su contraria ${ }^{38}$. $\mathrm{Na}$ verdade, diante do espectáculo de miséria intelectual, marcado pela incultura ou laivos de cultura aparente, ergue-se a voz resgatante de eruditos, filósofos e escritores.

Pela lição do texto e pela acção do homem, vem ao de cima um anseio de partilha de saberes e de experiências espirituais que é marca distintiva do agir discreto, seja com base em relaçôes de amizade alimentadas a partir de encontros regulares ou à distância (por meio de intenso intercâmbio epistolar), seja numa perspectiva ritualisticamente mais elaborada, como era o caso da academia, instrumento de difusão de valores simbólicos e de consequente afirmação pública da grandeza intelectual do indivíduo. Tudo leva a crer que, em se tratando de convívio erudito, a condição de nascimento não constituía entrave inultrapassável, mas convém ter presente que a sua obra, quando sujeita a um corte longitudinal, revela uma forte consciência elitista.

No seu desejo de tudo abarcar, mas sempre com incontestado mérito (pelo menos no plano da intençáo), o discreto tende a desenvolver um horizonte de criação de larga amplitude que se alimenta de uma base cultural enciclopédica, a cada instante renovada no seu vigor. À luz da erudição sem fronteiras que sempre postulou, Gracián exorta o leitor a passar além das «eminencias parciales» para poder gozar de «una perfecta universalidad» que as congregue a todas ${ }^{39}$. Só assim poderá aceder ao círculo restrito de "grandes hombres», «indefinibles, por su gran pluralidad de perfecciones, que repite a infinidad». Ora, numa inequívoca demonstraçáo das afinidades que entre o jesuíta e o escritor português é possível surpreender, tornando mais pertinente o que os aproxima do que tudo quanto os distingue, veja-se a reflexão que este desenvolve numa das Cartas Familiares, por ocasião do ofereci-

\footnotetext{
${ }^{37}$ El Discreto, realce V, p. 94.

${ }^{38}$ Obras Morales de Don Francisco Manuel, Vol. I, «Aparato a los lectores destas obras».

${ }^{39}$ El Discreto, realce VII, p. 98.
} 
mento de El Fenis de Africa Agustino Aurelio Obispo Hypponense sobre o alcance do saber de um «entendido» (termo que funciona, em regime de directa comutação, com o de discreto):

El que nació entendido en todo es entendido. Yo soy de parecer que la pereza, no el orden, introdujo la diferencia entre las facultades del arte. Ningún ingenio grande hemos visto que a partidos lo sea. Sólo esta monstruosidad no se atrevió a sacar en público naturaleza: hombre discreto y necio. Ignorar aquí y saber acullá infelicidad es por donde no ha pasado ninguno, siendo infinitos los que han pasado por no entender en ninguna parte. A todos tiempos y de todas cosas sabe el sabio y el ignorante ignora. Gran restitución cierto los ha infortunios de la sabiduría: ver que podrá la dicha subirle al indiscreto de estado, pero no de juicio. $\mathrm{Y}$ al sabio bajarle de premio, pero no de merecimiento. ${ }^{40}$

Quando redige o prólogo de História Geral de Etiópia, estampada em Coimbra no ano de 1660, faz acompanhar a sua apreciação das qualidades do Padre Baltasar Teles de uma reflexão que, por pertinente, vale a pena transcrever: «É prerrogativa dos talentos sublimes gozarem de uma mútua relação de ideias, que ũas com outras fidelissimamente se correspondem. Ser grande em ũa só parte quem nas outras é pequeno, antes o julgaríamos monstrosidade que a perfeição; ser douto em ũa só matéria, quem duvida que não é ser douto nem grande?»»1 . Reiterando esta ideia, que parece ter calado fundo no seu ânimo de homem e de escritor, há-de notar noutra de suas Cartas a propósito de certo «religioso que lhe deu a rever uns discursos militares»:

Conheço com dizer que a jurisdição dos discretos não prescreve com leis, nem por linhas se descreve. Sempre que posso, afirmo que o entendimento não tem portas que se cerrem para ũa ciência e para outra se abram. Contudo, ninguém me argua com outras tais afirmativas, quando não poucas vezes disse e tenho escrito: siga cada qual os passos da disciplina a que se ofereceu, porque o caçador que corre à lebre, náo vemos que se desvie para prender o gamo. Aquele que a toda a caça se lança, nenhũa alcança. ${ }^{42}$

Por recear gestos de intolerável precipitação ao nível do discurso oral ou escrito, o autor tende a refrear (sem que isso signifique, de modo algum, desprezar) o táo louvado «despejo», convidando à ponderação e ao discernimento:

el atrevimiento del juicio (dicho por mejor nombre, despejo) era lucida condición de los ingeniosos, y que un hablar, ó escribir confiado, se lleva de sabido más de medio aplauso. Saber de prontitudes es saber mujeril. Quiso naturaleza restituir a las mujeres

${ }^{40}$ Cartas Familiares. Prefácio e notas de Maria da Conceição Morais Sarmento, Lisboa, Imprensa Nacional Casa da Moeda, 1981, n. ${ }^{\circ}$ 180, p. 203. Para uma abordagem de aspectos relevantes ligados à cultura do discreto, pode consultar-se com proveito o ensaio de Aníbal Pinto de Castro, «D. Francisco Manuel de Melo, um polígrafo do Barroco ibérico", separata da Colectânea de Estudos em Homenagem ao Académico de Número Doutor Fernando Guedes no seu 75. Aniversário. Lisboa: Academia Portuguesa da História, 2004, pp. 129-145.

${ }^{41}$ Cartas Familiares, p. 503.

${ }^{42}$ Cartas Familiares, p. 160. 
en el desembarazo, lo que las había dado menos de prudencia. Pero en los hombres, en quien la virtud ponderatible tiene su asiento, más parece defecto, que gracia, la ligereza. ${ }^{43}$

Ainda que não ponha em causa a validade da actuação discursiva que a comunidade aristocrática assumiu como sinal distintivo da sua supremacia social, sempre faz notar que qualquer varão prudente que deseje alcançar o grau de excelência a que o comum nunca poderá aceder, ganha em percorrer uma via mais recatada:

No condeno la lozanía de los bien hablados, ni las sales cortesanas; su viveza, sus dichos, sus respuestas. Sé, todavía, no es esta la hacienda de ley del juicio; ni el caudal, en que hace su empleo la prudencia. Los antiguos, cuando entendieron a proponernos la imagen de un sabio, dibujaron todas las melancolías de Saturno, y la escuela de Chiron colgó toda de tinieblas el Griego. ${ }^{44}$

Tão longe leva este seu propósito de inculcar nos leitores o desejo de conquistar a eminência em todas as esferas de actuação que procura destrinçar, a dado passo de El Fenis de Africa, a linha de fronteira entre o perfil do sábio e o do discreto:

Los viejos leen por los ańos; los moços, ni por los años, ni por los libros pueden haber leído. El sabio, es librería; el discreto, cuando mucho, es cartapacio; donde, no más de apuntadas, y sin orden, agora parece, como a caso, rumiada la copla ajena; agora, poco fiel, la sentencia aprendida del oído. Gran ministerio encierra en sy la escritura, y a veces no concedido a todos que la manejan. Esto es cierto: siendo sin numero los autores, y en poco numero los celebrados. Saber escribir, no es solo saber escribir, sino saber, saber. ${ }^{45}$

Náo nos iludamos quanto ao real sentido destas palavras: a verdadeira sabedoria, qual quintessência, só está ao alcance de quem atingiu um estado de absoluta maturidade reflexiva e crítica, após longos anos de estudo e de profícuo contacto com o mundo e com os homens, a mais exigente escola de formação do varão eminente. Ora, com este gesto de clarificação semântica, o autor terá querido marcar a distância face à utilização intensiva (e, por isso mesmo, abusiva) da categoria do discreto, sobretudo entre os mais jovens. Salvo melhor opiniaáo, não se pretende questionar o paradigma da discrição em si, antes vincar bem o árduo caminho de perfectibilidade que, desde o berço à sepultura (para utilizar expressão de recorte quevediano), se institui e que Gracián, na estimulante síntese que remata o pequeno tratado consagrado a este modelo humano ( Culta repartición de la vida de un discreto»), procurou surpreender.

Sendo certo que, durante a existência humana, há sempre um tempo adequado para tudo, incluindo para manifestar aos olhos de outros o "caudal» com que cada um foi brindado, chega mesmo a advertir que:

${ }^{43}$ El Fenis de Africa Agustino Aurelio Obispo Hypponense, Primera Parte, Acción XIII («Un año después de ser maestro, se dispone a escribir libros. Compuso aquí los dos primeros de la Humana Hermosura. Estos se perdieron, con muchos otros de sus obras»), p. 75.

${ }^{44}$ El Fenis de Africa, Primera Parte, Acción XIII, p. 76.

${ }^{45}$ El Fenis de Africa, Primera Parte, Acción XIII, p. 76. 
El que se anticipa a dar temprano fruto de sabiduría no hace más que apresurarse a que le tengan por necio. Cuántos hemos venerado en su silencio, que en su voz despreciamos! [...] Tanto más presto se conoce el caudal del hombre, cuanto más en breve lo dezlía en la almoneda del mundo. [...] Suele, mil veces, acabarse tanto antes el aplauso, quanto más impacientes aspiramos a la admiración. Callando escribe el docto, porque el entendimiento, no debalde jeroglificado en la serpiente, bela a ojos cerrados. Habla y escribe el inorante; y pierde quanto tiempo piensa que aprovecha en lo que habla y escribe. ${ }^{46}$

Que a sabedoria não se deve ficar só pelo especulativo ou abstracto, mas requer contínua ilustração prática, até por não ser considerada um fim em si mesma, antes um meio para atingir a eminência, é o que lembra o Hospital das Letras: «os hábitos da erudição, em a própria maneira que se adquirem, se manifestam. Então diremos de um homem estudioso que é sábio, quando o virmos obrar e falar sàbiamente; porque entrar a doutrina e não sair da mente do homem, é mau sinal de bom logro dela ${ }^{47}$.

Dentre os muitos textos em que se sente ou pressente a presença da instância autoral é precisamente este quarto apólogo um dos mais relevantes (e a vários títulos). Desde logo, ao imiscuir-se no círculo restrito de autores que preenchiam o imaginário e o pensamento de um literato europeu de Seiscentos, num registo de absoluta e franca familiaridade, traça para si próprio um horizonte de elevada exigência e de inquestionável prestígio. Quando se depara com o catálogo exaustivo das suas obras, o leitor imediatamente percebe que na base desse processo técnico está o intuito de engrandecer a imago do autor, pois o que se pretende é suscitar o espanto. Disseminados pela sua vasta e multímoda obra, encontram-se traços que concorrem para a emergência do modelo arquetípico de homem «discreto» com desenvoltura de espírito e capacidade para cultivar diversos géneros literários ou glosar matérias culturais e políticas, parecendo vir agora reclamar para si a sua concretização efectiva e plena. Muito embora demonstre sentido de auto-crítica, num ou noutro ponto, quando avalia o seu desempenho como escritor, o que pode ajudar a contrabalançar o peso do encomiástico, o certo é que a tónica dominante é a do mérito do seu intenso labor. Consciente do palco privilegiado que tinha diante de si para sair em defesa das obras já publicadas, não hesitou em aproveitá-lo até onde o limite do decoro o consentia.

Nessa medida, procura incutir a ideia de que não há na sua vida, ao contrário do que acontece com a de homens vulgares (subentende-se), momento de ócio em que não afague o "honesto estudo»: «bem sabem os que me conhecem que quantas horas vivo, como escrevo; pois, porventura, não se poderão contar muitas de minha vida ociosas ${ }^{48}$, circunstância que Frei André de Cristo também sublinha no texto prefacial de El tercer coro de las Musas quando alude à "pluma que, jamás ociosa, salió desde su nido, a remontarse por las alturas de ajenos idiomas, de suerte que, a juicio de los proprios ingenios castellanos, hizo

\footnotetext{
${ }^{46}$ El Fenis de Africa, Primera Parte, Acción XIII, p. 74.

${ }^{47}$ Hospital das Letras, p. 104.

${ }^{48}$ Hospital das Letras, p. 103.
} 
miedo a los más cultos y cultivados dentro de su estudio proprio» ${ }^{49}$. É tal o empenho posto nesta estratégia que chega a enunciar, no texto do citado apólogo, factos prodigiosos, como as vinte e duas mil cartas familiares que em poucos anos escreveu, ou sinais de estupefacção da parte das outras personagens que amplificam o efeito causado.

Para que se possa ver, com luminosa nitidez, a forma como concebe o lugar do saber (essa «cultura del espíritu» que nem sempre consegue ombrear, na sociedade do tempo, com a «cultura de la persona») no âmbito geral de formação do indivíduo e sobre a correlação entre ciência e poder no caso particular dos príncipes, é útil considerar esta sua reflexão:

gran falta y más que grande desdicha es que un hombre todo lo desee perfecto, sino a sí mismo! Y, siéndole más fácil hermosear el ánimo que el cuerpo, tanto se cuide la cultura de la persona, y tampoco de la del espíritu! Entiendo yo que ningún cuerdo dejará antes de sacar un vestido de buriel aforrado en preciosas martas, que otro de bellísima tela con aforros de vellorí. Todavía a menor precio me contentaré en los señores, que el que les ponía Platón en su República, ordenando reinasen los filósofos, o filosofasen los reyes. También hallo embarazo en tanta sabiduría, porque juzgo que no corre más peligro la pólvora junto al fuego, que la ciencia junto al poder. Lo que dejó advertido Aristóteles cuando dijo: ella inflamaba al corazón que la poseía. Deseo más en los Príncipes la prudencia que la ciencia, porque el ministerio de Rey formalmente difiere del de Maestro. Siendo en los Príncipes una alta razón de estado humillarse tal vez a la ignorancia, porque los más somos tales que gustamos de ver errar al que piensa lo sabe todo; y aun al que todo lo sabe, si alguno que todo lo sepa. Quién se aventurará a llevarle a otro un presente de aquello que está viendo que le sobra y a veces desperdicia? Pero la causa aun no és ésta, sino que, como los hombres no pueden igualar a los Reyes, en el poder (que por razón convino fuera de uno sólo), no consienten que también en el saber le excedan los Reyes, siendo el entendimiento potencia liberal, libre y para todos. ${ }^{50}$

Numa outra perspectiva, o apólogo dialogal pode ser lido como demonstração do "gosto», na acepção gracianesca do termo, do autor que o elaborou, na medida em que a avaliaçáo crítica que nele se leva a cabo pressupóe uma capacidade de discernimento e de eleição que só está ao alcance de alguns. Como já fizemos questão de notar, entre os muitos atributos com que o jesuíta dotou o seu modelo de homem discreto contava-se, e em lugar destacado, a «buena elección» ou o «buen gusto». Melhor do que ninguém, ele compreendeu que o estudo ou mesmo o engenho não bastavam para assegurar a pretendida supremacia sobre os demais: era necessário saber escolher o mais belo ou o melhor da natureza e da arte. No realce X de El Discreto, consagrado precisamente ao «hombre de buena elección», declara que "no hay perfección donde no hay elección. Dos ventajas incluye: el poder elegir y eligir bien» e lamenta que muitos de «ingenio sutil, de juicio acre, estudiosos y noticiosos» quando confrontados com o imperativo da escolha vacilem e nem

${ }^{49}$ El tercer coro de las Musas del Melodino, «Epístola a los lectores. Por un aficionado del Autor y del estudio poético", in Obras Métricas. Vol. II, ed. coordenada por Maria Lucília Gonçalves Pires e José Adriano de Freitas Carvalho. Braga: Ediçóes APPACDM de Braga, 2006, p. 806.

${ }^{50}$ Cartas Familiares, n. ${ }^{\circ}$ 35, pp. 82-83. 
sempre optem pelo melhor caminho, seja em que área for ${ }^{51}$. É evidente que aqui nos interessa sobretudo a vertente estética da noçáo de «buen gusto», mas importa lembrar, na senda do trabalho realizado por investigadores como Emilio Hidalgo-Serna, que se trata de uma "piedra angular de la arquitectura filosófica»" ${ }^{52}$ do jesuíta, pelo que tem um alcance muito mais lato do que aquele que aqui manifestamos.

Ora, a partir do momento em que Melo, servindo-se de um núcleo restrito de personagens, julga o mérito ou o demérito desta ou daquela obra está a exercer essa faculdade de eleição que, nas palavras de Gracián, constitui «uno de los más importantes favores de la naturaleza, comunicado a pocos, porque la singularidad y la excelencia doblen el aprecio" ${ }^{53}$. Em última instância, o seu padrão de "buen gusto», trabalhado ao longo de anos com base num impressionante cabedal de leituras e numa profícua convivência (não necessariamente presencial) com amigos e homens sábios, pode actuar de modo estimulante sobre o leitor e conduzi-lo ao domínio do saber engenhoso. Uma obra como o Hospital das Letras dificilmente poderia ser composta noutra fase da sua vida que não a da maturidade, quanto mais náo fosse por uma questão de coerência: é o olhar de quem contempla, com o distanciamento que só o tempo proporciona, um caminho já percorrido. Até em termos formais, a utilização do modelo conversacional não poderia estar mais de acordo com essa «sabiduría cortesana» ou "conversable sabrosa erudición» que não está ao alcance dos que frequentam os tradicionais meios de formação escolar, mas só dos que têm acesso a ambientes restritos e refinados. Ouçamos, uma vez mais, a autorizada voz de Gracián, porque define, de modo insuperável, o que nos parece ser o núcleo essencial da lição veiculada pelos apólogos dialogais: «un modo de ciencia es este que no lo enseñan los libros ni se aprende en las escuelas; cúrsase en los teatros del buen gusto y en general tan singular de la discreción " ${ }^{54}$.

Para um autor que se preza de discreto e que se dirige a um leitor que também o é, ou pretende ser, tão relevante é o modo por que se manifesta o saber como este considerado em si mesmo. Nessa medida, compreende-se que as múltiplas formas de agudeza e de procedimento engenhoso tenham conquistado um lugar de eleição no âmbito da interacção discursiva que decorria em distintos palcos do agir social do tempo ${ }^{55}$. Essa palavra viva e flamante tornou-se condição essencial para agradar e impressionar leitores, mas sobretudo ouvintes, porque é no campo da oralidade que se encontra o seu terreno de

${ }^{51}$ Baltasar Gracián, El Discreto, realce X, pp. 103-106 (cujo conteúdo aparecerá depois reproduzido, de modo abreviado, no aforismo LI do Oráculo manual y arte de prudencia).

52 Emilio Hidalgo-Serna, El pensamiento ingenioso en Baltasar Gracián. El «concepto» y su función lógica. Barcelona: Editorial Anthropos, 1993, p. 170.

${ }^{53}$ El Discreto, realce X, p. 103.

${ }^{54}$ El Discreto, realce V («Hombre de plausibles noticias»), p. 92.

55 Como facilmente se deduz, quanto mais insinuante se mostra a estratégia compositiva, seja ao nível da inventio, da dispositio ou da elocutio, tanto mais prezado se torna o produto final para o homem de agudo engenho. Contra o que seria de esperar (sobretudo na óptica de um leitor contemporâneo), o texto inscreve-se num horizonte de opacidade que deixa perceber, com base em pistas mais ou menos dissimuladas, efeitos de sentido a recuperar. De posse do(s) código(s) adequado(s), socialmente partilhados pelos sujeitos de enunciação e destinatários, é possível decifrar tudo quanto originalmente aparecia cifrado por meio da palavra (ou da representaçăo iconográfica) imaginativa, mesmo o que, à primeira vista, se mostrava enigmático. 
eleição. Em clave engenhosa e aguda se projecta certa margem de gozo estético que não impede, antes estimula, a indagação conceptual.

Por outro lado, só um engenho com certo nível de maturidade consegue elaborar conceitos, estabelecendo correspondências inesperadas entre objectos que, à partida, nada parecem ter em comum, abrindo assim caminho a uma concepçáo do mundo e da actividade cognoscitiva que, passando além de critérios lógico-racionais, considera legítima e produtiva para a averiguaçáo da natureza constitutiva de cada ser ou coisa a teia de relaçóes que permite aproximá-los dos restantes objectos que preenchem o real. Desse ponto de vista, e na linha do que acontecia com outras áreas de afirmação da cortesania, oferece o corpus textual que Melo nos legou não só um manancial de pertinentes manifestaçóes, como um exercício de sistemática reflexão que visa apurar o domínio de tais faculdades junto de potenciais destinatários ${ }^{56}$.

Tudo ponderado, cremos que poucos encarnaram tão bem, na carne e no espírito, esse modelo do varáo prudente e discreto como Melo o fez e em menor número ainda foram os que (sobretudo no âmbito geográfico-cultural luso-brasileiro) souberam reflectir criticamente sobre os fundamentos que o suportam. Nessa medida, compreende-se que tenha querido, muitas vezes, evitar o travo especulativo ou escolástico que se fazia sentir em boa parte da tratadística da época, caminhando no sentido de uma formulação mais próxima ao viver mundano e cortesão, pelo atractivo do jogo dialéctico e pela grata leveza da arte, o que não significa de todo menor esforço reflexivo.

\footnotetext{
${ }^{56} \mathrm{Um}$ dos casos mais flagrantes é seguramente o de Apólogos Dialogais, uma vez que o jogo dialógico que está na sua base constitui, em si mesmo e por meio dos preceitos explícitos transmitidos pelas dramatis personae, um exercício performativo modelar, pela íntima comunhão entre o que se diz e o modo como se diz. Com regular insistência, o assunto do discurso passa a ser o do seu próprio andamento e ainda que as reflexốes apresentadas em contexto literário não possam (ou não devam) ser transpostas de forma directa para o plano do real, julgamos ser possível reconhecer ainda assim as traves-mestras de uma poética implícita.
} 
Série

Documentos

Imprensa da Universidade de Coimbra

Coimbra University Press

2010

- U

C • 